\title{
Relation of Hypothyroidism on BMI and Dyslipidemia
}

\author{
Nasir Uddin Ahmed*1, Md. Anwarul Kabir², Abdur Razzak³, Maj Shaheda Akter ${ }^{4}$
}

\section{Abstract}

Introduction: Hypothyroidism is a common medical disorder in the general population especially in women. Over-weight, obesity and dyslipidemia are major public health problem in both developed and developing countries. The present study is an effort to determine the association between hypothyroidism with body mass index (BMI) and dyslipidemia. Materials and Methods: This is a cross sectional descriptive type of observational study of 100 cases of primary hypothyroidism in the age group 15-75 years of both sexes from February 2018 to January 2019 in CMH, Momenshahi. BMI was measured by weight in $\mathrm{kg} /$ height in $\mathrm{m}^{2}$ and lipid profiles were analyzed by semi-automated biochemistry analyzer. Data was analyzed by X-cel. Results: Among 100 cases mean BMI were $28.51 \pm 4.52,75$ cases $(75 \%)$ obese, $16(16 \%)$ over-weight, $8(8 \%)$ normal. Mean serum cholesterol, Triglyceride (TG), high density lipoprotein (HDL) and low density lipoprotein (LDL) are 195.1 \pm 44.57 , $164.49 \pm 83.87,40 \pm 3.91$ and $122 \pm 41 \mathrm{mg} / \mathrm{dl}$ respectively. Conclusion: Here data statistically showed primary hypothyroidism is significantly correlated with high BMI and serum cholesterol, TG, LDL levels were also significantly correlated to this disorder. But HDL is not correlated with primary hypothyroidism.

Key words: Primary hypothyroidism, Body mass index (BMI), Triglycerides (TG), High density lipoprotein (HDL), Low density lipoprotein (LDL), Cholesterol.

Number of Figures: 05; Number of Table: 01; Number of References: 32; Number of Correspondences: 04

*1. Corresponding Author:

Lt Col Dr. Nasir Uddin Ahmed

MBBS, FCPS (Medicine)

Department of Medicine

CMH Momenshahi.

2. Brig Gen Dr. Md. Anwarul Kabir

MBBS, FCPS (Medicine)

DEM (Diploma Endocrinology \& Metabolic Disorder)

Department of Medicine

CMH Dhaka.

3. Brig Gen Dr. Abdur Razzak MBBS, MCPS, FCPS

Fellow in Rheumatology

4. Dr. Maj Shaheda Akter

MBBS, MCPS

(Radiology and imaging)

Department of Radiology and imaging

CMH Momenshahi.

\section{Introduction}

Thyroid disorders are common in the general population, with hypothyroidism being the predominant disorder in the adult population ${ }^{1,2}$. Thyroid hormone plays a very key role in energy homeostasis and is directly involved in glucose $e^{3}$ and lipid metabolism ${ }^{4,5}$. The spectrum of presentation ranges from fatigue or mild forgetfulness to a severe impairment of consciousness termed myxedema coma ${ }^{6}$. Over weight and obesity are major public health problems in both developed and developing countries? A number of large epidemiological studies proved that mortality increases with obesity ${ }^{8-10}$. Weight reflects health and nutritional status and adjusted for height is a useful tool to predict fitness and Body Mass Index $(\mathrm{BMI}=$ weight in $\mathrm{kg} /$ height in meter $^{2}$ ) is a useful proxy measure of adiposity.

Though thyroid stimulating hormone levels were progressively increased according to the severity of obesity and were positively correlated with body mass index (BMI) ${ }^{11}$ yet the opposite suggestion had also been put forwarded that TSH was not correlated with $\mathrm{BMI}^{12}$. Thyroid function significantly affects lipoprotein metabolism as well as some cardiovascular risk factors thus influencing overall CVD risk ${ }^{13-15}$. Indeed, hypothyroidism is a common cause of secondary dyslipidemia ${ }^{16-17}$.

The aim of the present study was to investigate the correlation of hypothyroidism with BMI and dyslipidemia.

\section{Materials and Methods}

This was a cross sectional descriptive type of observational study of hypothyroidism patients where a total of 100 were studies during February 2018 to January 2019. All those patients were seen in medical outdoor department of Combined Military Hospital ( $\mathrm{CMH}$ ) Momenshahi. A detailed history and clinical examination were carried out in a predesigned case report form.

\section{Blood collection and sample preparation}

After 12 hours overnight fasting venous blood was taken from patients of hypothyroidism with dry disposable syringe and needle under taking all aseptic precaution. Serum FT4, TSH were measured by chemiluminescence immune assay by ELECSYS 1010. Patients with TSH over $6 \mu \mathrm{IU} / \mathrm{ml}$ and above were considered are to be having hypothyroidism.

Body mass index (BMI) was measured by height in $\mathrm{kg} / \mathrm{m}^{2}$. BMI more than 23 and 25 were considered as overweight and obese respectively in this study. Fasting lipid profiles were carried out 
by semi-automated biochemistry analyzer.

Inclusion criteria are patients of both sexes attending OPD in $\mathrm{CMH}$, age limit from 13 to 70 years and presented with suspected case of hypothyroidism.

Exclusion criteria are hepatitis including liver cirrhosis, hepatotoxic drug intake, associated any debilitating illness and pregnant women.

\section{Results}

Fig-1: Pie chart showing 95\% are female and 5\% are male.

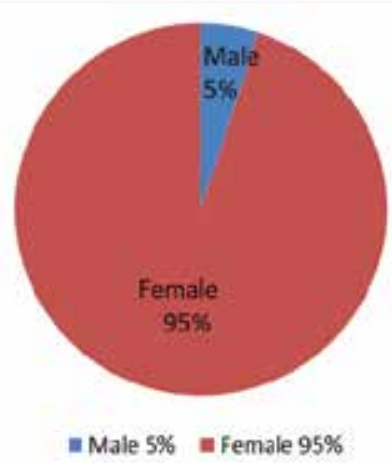

Fig-1: Sex Variation $(\mathrm{n}=100)$.

Fig-2: Bar chart showing age of presentation. $<15$ yrs only $1(1 \%), 16-25$ yrs $11(11 \%), 26-35$ yrs $56(56 \%), 36-45$ yrs $26(26 \%), 46-55$ yrs $3(3 \%), 66-75$ yrs $1(1 \%)$. Minimum age of presentation $13 \mathrm{yrs}$ and maximum $70 \mathrm{yrs}$.

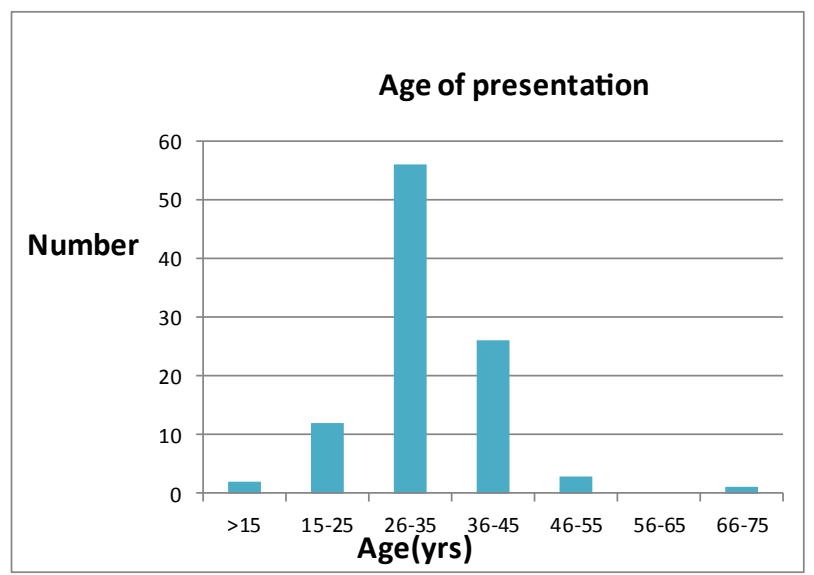

Fig-2: Presentation of Different age group $(n=100)$.

Fig-3: Bar chart showing clinical presentation of hypothyroidism patients. Most of the patients $(18 \%)$ presented with vague symptoms like general weakness, $15 \%$ with menstrual irregularity, $14 \%$ with weight gain. Other presentations are thyroid swelling(11\%), subfertility $(10 \%)$, leg swelling( $8 \%)$, body ache $(8 \%)$, incidental finding $(5 \%)$, abortion( $4 \%)$, cold intolerance $(2 \%)$, decreased libido( $2 \%)$, alopecia(1\%), whitish spots $(1 \%)$ and recurrent syncope (1\%).

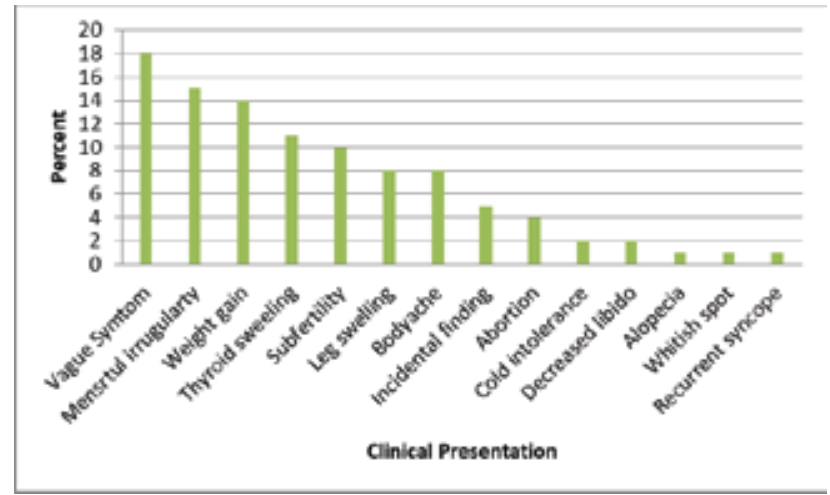

Fig-3: Clinical presentation of hypothyroidism.

Fig-4: Barr chart showing mean level of cholesterol, TG, HDL and LDL 195.14 $\pm 44.57,164.49 \pm 83.87,40 \pm 3.91$ and $122 \pm 41.72$ respectively ( $i n \mathrm{mg} / \mathrm{dl}$ ) which is much more higher than mean level of general population.

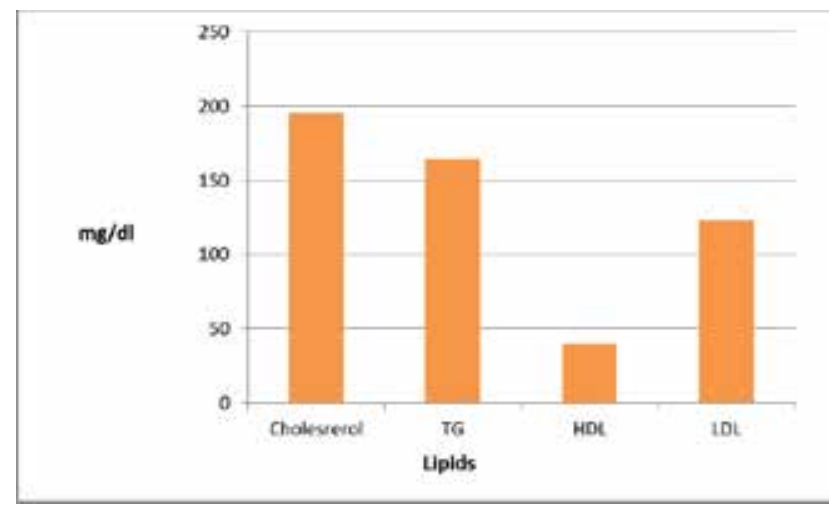

Fig-4: Mean level of lipid profile (F).

Fig-5: Pie chart showing out of 100 cases $75(75 \%)$ are obese, $17(17 \%)$ over weight, $8(8 \%)$ normal and no underweight.

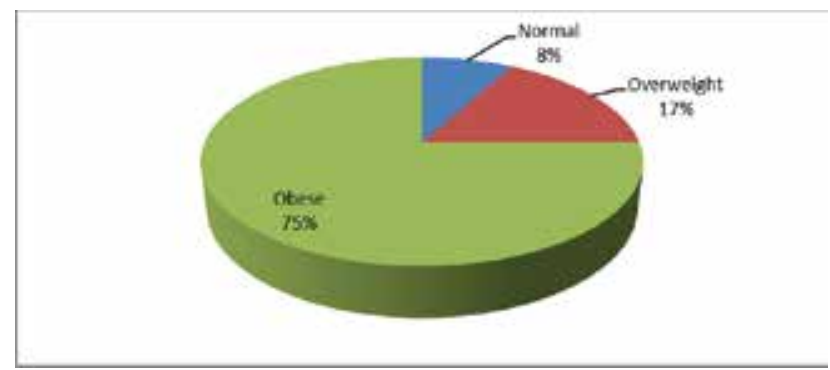

Fig-5: BMI Status $(n=100)$.

Table-I: showing mean, minimum and maximum height, weight and BMI. Mean height, weight and BMI were $1.53 \pm .07 \mathrm{~m}, 66.93 \pm 10.76 \mathrm{~kg}$ and $28.51 \pm 4.52$ respectively.

Table- I: Height, Weight \& BMI ( $\mathrm{n}=100)$.

\begin{tabular}{lccc}
\hline & Height \pm SD & Weight \pm SD & BMI \pm SD \\
\hline Mean & $1.53 \pm .07 \mathrm{~m}$ & $66.93 \pm 10.76 \mathrm{~kg}$ & $28.51 \pm 4.52$ \\
Min & $1.244 \mathrm{~m}$ & $45 \mathrm{~kg}$ & 18.14 \\
Maximum & $1.778 \mathrm{~m}$ & $95 \mathrm{~kg}$ & 39.57 \\
\hline
\end{tabular}




\section{Discussion}

World health organization (WHO) has recommended classification of body weight that include degree of underweight and gradation of excess weight or overweight that are associated with increased risk of some non-communicable diseases ${ }^{18,19} \mathrm{BMI}$ is calculated as weight in kilogram divided by height in meters squared $\left(\mathrm{kg} / \mathrm{m}^{2}\right)$ and it is easy to obtain ${ }^{20}$. For Asian people cut-off point of $\mathrm{BMI}$ is little lower than international standard. For Asian BMI more than 23 is considered as overweight and more than 25 is considered as obese.

In our study out of total 100 patients no underweight case is seen. BMI in normal range was $8(8 \%)$, overweight 17 (17\%) and obese 75 (75\%). Prevalence of overweight and obese in Bangladesh is $17 \%$, out of them $4 \%$ are obese only ${ }^{21}$.

In the present study we have found that high BMI is significant in hypothyroidism patients (with $\mathrm{z}$ value 19.70 and $p$ value 0.000 which is $<0.005)$ and positively associated in both sexes. These findings are similar to the findings of A Nyrnes et al ${ }^{22}$ and G. Lacobellis et $\mathrm{al}^{23}$.

In our findings among hypothyroidism patients obese are $75 \%$ which is much more than the prevalence of obesity in Bangladesh. Hypothyroidism is a risk factor for obesity, in spite of that other factors may be responsible for this high percentage of obesity. Study was conducted among Armed Forces personnel and their family members intake more calorie than general population of Bangladesh. Beside that in our study group maximum are female usually having more BMI than male.

Thyroid disorder especially hypothyroidism is more common in female ${ }^{24}$. Though our female male ratio much higher than other findings $\mathrm{s}^{25}$. This can be explained by the sample we have taken from Armed Forces personnel and their family members. The male are recruited after proper medical check-up but their wives are not.

Thyroid hormones play an important role in regulating body weight, lipid metabolism and insulin resistance all of these cause increase BMI. The recent discovery of leptin, a peptide hormone produced by adipose tissue, has led to a renewed interest in the pathophysiology of obesity; some studies have focused on the relationship between leptin and energy expenditure as well as thyroid function ${ }^{26}$.

The level of leptin is directly correlated to the amount of adipose tissue and leptin has been reported to stimulate the biosynthesis of TSH in vitro. Furthermore, there is synchronicity between secretion of leptin and TSH both in children $^{27}$ and adults ${ }^{28}$. In our findings mean cholesterol, TG, LDL were 195.14 $\pm 44.57, \quad 132.5 \pm 35.3$ and $122.98 \pm 41.72 \mathrm{mg} / \mathrm{dl}$ which were significantly correlated with hypothyroidism ( $\mathrm{p}$ value $0.0002,0.000$ and 0.000 respectively). On the contrary serum HLD level was $40 \pm 3.91 \mathrm{mg} / \mathrm{dl}$ which is not significantly correlated with hypothyroidism. Thyroid hormones are involved in both lipogenesis and lipolysis ${ }^{29}$; an effect that possibly is mediated by affecting local nor adrenalin level and or adrenergic post receptor signaling ${ }^{30}$.

This high level of lipid may be due to reduction in the hepatic LDL receptors, and a decreased hepatic cholesterol catabolism by the T3-regulated 7-alpha-hydroxylase enzymes $^{31}$. On the other hand, hypothyroidism is associated with increased oxidation of LDL particles. Such modification of LDL particles can impair their receptor-mediated uptake causing accumulation ${ }^{32}$.

\section{Conclusion}

The results of present study confirmed the correlation between hypothyroidism and BMI. Overweight and obesity are interlinked to high TSH level. It is also confirmed that fasting serum cholesterol, TG and LDL levels were significantly correlated with primary hypothyroidism. While treating hypothyroidism patients clinician should always care about dyslipidemia and high BMI also.

Conflict of Interests: None.

\section{Acknowledgement}

The authors are grateful to Md Jamal Hossain, Assistant Professor, Agriculture Statistics, Bangladesh Agricultural University who has given support for preparing the article.

\section{References}

1. Rizos CV, Elisaf MS, liberopulos EN. Effects of thyroid dysfunction on lipid profile. Open cardiovasc Med J. 2011; 5: 76-84.

https://doi.org/10.2174/1874192401105010076

PMid:21660244 PMCid:PMC3109527

2. $\mathrm{Wu} \mathrm{P}$. Thyroid disease and diabetes. Clin Diabetes. 2000; 18: 38-40.

3. Mc Aninch EA, Bianco AC. Thyroid hormone signaling in energy homeostasis and energy metabolism. Ann NY Acad Sci. 2014; 1311: 77-87.

https://doi.org/10.1111/nyas. 12374

PMid:24697152 PMCid:PMC4451242

4. Cordeiro A, Souza LL, Einicker-Lamas M, Pazos-Moura CC. Non-classic thyroid hormone signaling involved in hepatic lipid metabolism. J Endocrinol. 2013; 216: R47-56. https://doi.org/10.1530/JOE-12-0542

PMid:23297113

5. Muller, R. Liu, Y.Y., Brent, G.A. Thyroid hormone regulating of metabolism. Physiol Rev. 2014; 94: 355-382.

https://doi.org/10.1152/physrev.00030.2013

PMid:24692351 PMCid:PMC4044302

6. Bijay V, Simon H. Management of hypothyroidism in adults. BMJ. 2008; 337: a 801.

https://doi.org/10.1136/bmj.a801

PMid:18662921

7. Kaider-Person O, Bar-Sela G, Person B. The two major epidemics of twenty-first century: obesity and cancer. Obes Surg. 2011; 13: 1792-1797. 
https://doi.org/10.1007/s11695-011-0490-2

PMid:21842287

8. Freedman DM, Ron E, Ballard-Barbash R, Doody MM, Linet MS. Body mass index and all cause mortality in a nationwide US cohort. Int I Obes (Lond ). 2006; 30: 822-9. https://doi.org/10.1038/sj.ijo.0803193

PMid: 16404410

9. Price GM, Uauy R, Breeze E, Bulpitt CJ, Fletcher AE. Weight, shape and mortality risk in older persons: elevated waist hip ration, not high body index, is associated with greater risk of death. Am J Clin Nutr. 2000; 84: 449-60.

https://doi.org/10.1093/ajcn/84.2.449

10. Pischon $T$, Boeing $H$, Hoffman $K$, Bergmann $M$, Schulze MB, Overvad K. General and abdominal adiposity and risk of death in Europe. N Engl J Med. 2008; 359: 405-20.

https://doi.org/10.1056/NEJMoa0801891

PMid: 19005195

11. Stone NJ. Secondary causes of hyperlipidaemia. Med Clin North Am. 1994; 78:117-42.

https://doi.org/10.1016/S0025-7125(16)30179-1

12. J Zhang, H Sun, L Chen, J zheng, X Hu, S wang, et al. Relatindhip between serum TSH level with obesity and NAFLD in euthyroid subject. J Huazhang Univ Sci Technol ( Med Sci ) . 2012; 32(1): 47-52.

https://doi.org/10.1007/s11596-012-0008-8

PMid:22282244

13. Duntas LH. Thyroid disease and lipids. Thyroid. 2002; 12: $287-9$.

https://doi.org/10.1089/10507250252949405

PMid:12034052

14. Friis T, Pedersen LR. Serum lipid in hyper and hypothyroidism before and after treatment. Clin Chim Acta. 1987; 162: 155-63.

https://doi.org/10.1016/0009-8981(87)90447-5

15. Canaris W, Manowitz NR, Mayor G, Ridgway EC. The Colorado thyroid disease prevalence study. Arch Intern Med. 2000; 160: 526-34.

https://doi.org/10.1001/archinte.160.4.526

PMid:10695693

16.Tsimihodimos V, Bairaktari E, Tzallas C, Miltiados G, Liberopoulos E, Elisaf M. The incidence of thyroid function abnormalities in patients attending an outpatient lipid clinic. Thyroid. 1999; 9: 365-8.

https://doi.org/10.1089/thy.1999.9.365

PMid:10319942

17. Ortiga-Carvalho TM, Oliviera KJ, Soares BA, Pazos-Moura CC. The role of leptin in the regulation of TSH secretion in the fed state: inn vivo and vitro studies. $\mathbf{J}$ Endocrinol. 2002; 174: 12-125.

https://doi.org/10.1677/joe.0.1740121
18. WHO. Physical status: the use and interpretation of anthropometry, Reort of WHO expert consultation, WHO technical report series number 854, Geneva; World Health Organization.

19. WHO. Obesity: Preventing and managing of global epidemic. Report on WHO consultation on obesity, Geneva, 3-5 June,1997.

20. WHO Expert Consultation: Appropriate body mass index for Asian population and its implication for policy and intervention strategies. Lancer. 2004; 363: 157-63.

https://doi.org/10.1016/S0140-6736(03)15268-3

21. http://www.icddrb.org>dmdocuments

22. De Pargola G, Ciampolillo A, Palotti S, Trerotoli P, Giorgino R. Free triiodothyronine and thyroid stimulating hormone are directly associated with waist circumference, independently of insulin resistance, metabolic parameters and blood pressure an overweight and obese women. Clin Endocrinol (Oxf). 2007; 67: 265-9.

https://doi.org/10.1111/j.1365-2265.2007.02874.x

PMid: 17547687

23. Gianluca L, Maria CR, Alessandra Z, Concetta VL, Frida L. Realationship of thyroid function with body mass index, leptin, insulin sensitivity and adiponectin in euthyroid obese women. Clin Endocrinol. March 2005; 62:5.

https://doi.org/10.1111/j.1365-2265.2005.02247.x PMid: 15807881

24. Landerson PW, Singer PA, Ain KB. American Thyroid Association guidelines for detection of thyroid dysfunction. Arch Inern Med. 2000; 160(11): 1573-1573.

https://doi.org/10.1001/archinte.160.11.1573

25. Ambika GU, Sanjay K, Neeraj T. Prevalence of hypothyroidism in adults: An epidemiological study in eight cities of India. Indian J Endocrinol Metab. Jul-Aug 2013;17(4):647-651.

26. Mariantonella T, Maria E, Giovanna C, Alessandro M, Giulio S. Subclinical hypothyroidism in obese patients: Relation to resting energy expenditure, serum leptin, body composition and lipid profile. Obesity Research. March 2001; (9).

https://doi.org/10.1038/oby.2001.21

PMid:11323445

27. Ghizzoni L, Mastorakos G, Ziveri M, Furlini M, Solazzi A, Vottero A,et al. Interaction of leptin and thyrotropin 24-h secretory profiles in short normal children. J Clin Endocrinol Metab. 2001; 86: 3284-3290.

https://doi.org/10.1210/jcem.86.8.7758

https://doi.org/10.1210/jcem.86.5.7452

PMid: 11344208

28. Mantzoros CS, Ozata M, Negrao AB, Suchard MA, Ziotopoulou M, Caglayan S, et al. Synchronicity of frequently sampled thyrotrophin (TSH) and leptin 
concentrations in leptin deficient subjects: evidence for possible partial TSH regulation by leptin in humans. J Clin Endocrinol Metab. 2001; 86: 3284-3291.

https://doi.org/10.1210/jcem.86.7.7644

PMid: 11443202

29. Diamant S, Gorin E, Shafrir E. Enzyme activities related to fatty acid synthesis in liver and adipose tissue of rats treated with triiodothyronine. Eur J Biochem. 1972; 26: 553-559.

https://doi.org/10.1111/j.1432-1033.1972.tb01798.x

PMid:5025931

30. Halazik M, Nedvidkova J, Bartak V, Dostalova I, Vicek P, Racek P, et al. Effects of hypo or hyperthyroidism on non adrenergic activity and glycerol concentration in human subcutaneous abdominal adipose tissue assessed with microdialysis. J Clin Endocrinol Metab. 2003; 88: 5605-5608.

https://doi.org/10.1210/jc.2003-030576

PMid: 14671140

31. Droper VA, Agellon LB. Regulation of the human cholesterol 7-alpha-hydroxylase gene (CYP7A1) by thyroid hormone in transgenic mice. Endocrinol. 2004; 145: 574-581.

https://doi.org/10.1210/en.2003-0993

PMid:14592954

32. Hermann T, Baumiester SE, Volzke H, Wasner C, Schminke UH, et al. Are serum TSH level associated with oxidized low-density lipoprotein? Results from the study of health Pomerania. Clin Endocrinol (Oxf). 76:526-532.

https://doi.org/10.1111/j.1365-2265.2011.04186.x

PMid:21848645 